\title{
Editorial
}

\section{The British Journal of Nutrition, an international journal that continues to develop}

I have been Editor-in-Chief of the British Journal of Nutrition $(B J N)$ for six months now. So far the experience has been a generally enjoyable one, although not without its challenges and difficulties. One frustration has been the occasional comment that $B J N$ 'is a British journal', with an underlying suggestion that the journal is run entirely by the British and that it does not publish too much research from outside the United Kingdom. My response has been to suggest that the originator of the comment obviously doesn't look at the journal! In fact the signs that $B J N$ is a truly international journal are rather evident. The cover carries the title 'BJN: An International Journal of Nutritional Science', although on-line users of the journal probably do not spend too much time looking at the cover! Of the three Deputy Editors of $B J N$, one is German and another American. The Editorial Board includes members from fifteen countries. Only $40 \%$ of the Editorial Board is British, there are seventeen members from seven countries in Continental Europe, eleven North American members, and members from China, Japan, Australia and New Zealand. Manuscript reviewers cover a similarly wide geographical spread. Thus, there is plenty of evidence that those responsible for reviewing and making decisions on manuscripts represent an international mix. What about the origin of papers published in $B J N$ ? Browsing the contents of any issue will reveal quite a mix of countries of origin of published papers. Table 1 provides a breakdown of the regions of affiliation of corresponding authors of papers published in $B J N$ in 2005. This table demonstrates the remarkable geographical diversity of the papers we publish and, I think, demonstrates the true international nature of the journal. It is noteworthy that only about $20 \%$ of papers published in $B J N$ in 2005 were from the United Kingdom. Papers were published from sixteen other European countries, corresponding to over $45 \%$ of total publications, with France (10\% of papers), Germany (7.5\% of papers), Spain (6\% of papers) and The Netherlands $(5.5 \%$ of papers) being prominent. Scandinavian countries contributed $7 \%$ of published papers. Papers were published from two North American countries (USA (6.5\% of papers) and Canada), two South American countries (Brazil and Argentina), South Africa, six Asian countries (Japan (6\% of papers), China, Taiwan, South Korea, India and Singapore), Australia and New Zealand.

In my Editorial in January of this year (Calder, 2006) I highlighted and paid tribute to the many changes to the journal introduced during the Editorships of my predecessors Keith Frayn and Paul Trayhurn. I stressed that these changes have served to significantly improve the journal for subscribers, readers and authors. One major development in this respect is the relatively recent on-line availability of the entire archive of $B J N$ right back to volume 1, issue 1 in September 1947. In my January 2006 Editorial, I also commented that scientific publishing is evolving rapidly and that further changes would be introduced with the aim of further improving the service that $B J N$ offers its users and of assuring an enhanced status for the journal. On-line subscribers will have noticed the relatively recent availability of Fast Track papers; these are papers that have not yet been published but which are available in their final, ready-to-be-published form (i.e. as corrected proofs). This means that authors' work is available to on-line subscribers some weeks prior to publication. I have recently made the decision to make authors' work available much sooner than this. From some time later this year or early in 2007 accepted manuscripts will be available to on-line subscribers, meaning that authors' work will be accessible (to those with an on-line subscription) some months before publication of the paper. The aim is to make research findings available to peers much more quickly than occurs at present, which will enhance the usefulness and appeal of the journal to readers and increase the visibility, accessibility and impact of authors' work. This is likely just one of many developments that will occur over the next few years as publishing and use of journals relies more on electronic access and is able to capitalise on the possibilities that this offers. I trust that subscribers, readers and authors will find these developments of value.

My predecessor typically used his Editorial at this time of year to identify and comment on highly cited articles published in BJN over the previous few years (Trayhurn, 2002, 2003, 2004, 2005). I elected to do this in my January Editorial (Calder, 2006) when the impact factor and other statistics related to journal performance were available and I intend to continue with this cycle. However, I think that it is valuable to preview some of the most highly cited papers of 2003 and 2004 at this point, since these will determine the impact factor of the journal for 2005. Table 2 lists the thirteen papers published in $B J N$ in 2003 and 2004 that were most highly cited in 2005. It is gratifying to see the high rate of citation of these papers which is indicative of the $B J N$ publishing material that is valuable to others. The list of highly cited papers once again highlights the importance of Review and Horizons in Nutritional Science articles in assuring the high profile and impact of $B J N$. I eagerly await the announcement of the impact factor of $B J N$ for 2005 and the related statistics, and I will report on these in my Editorial in January 2007. 
Table 1. Regions of affiliation of corresponding authors of articles published in the British Journal of Nutrition during 2005

\begin{tabular}{|c|c|c|c|c|c|c|c|c|}
\hline \multirow[b]{2}{*}{ Region } & \multicolumn{2}{|c|}{$\begin{array}{l}\text { Full papers \& Short } \\
\text { communications }\end{array}$} & \multicolumn{2}{|c|}{$\begin{array}{l}\text { Other articles published in } \\
\text { main issues }{ }^{*}\end{array}$} & \multicolumn{2}{|c|}{$\begin{array}{l}\text { Articles published } \\
\text { in Supplements }\end{array}$} & \multicolumn{2}{|c|}{ Total } \\
\hline & $n$ & $\%$ & $n$ & $\%$ & $n$ & $\%$ & $n$ & $\%$ \\
\hline Europe (of which UK) & $151(48)$ & $65.4(20.8)$ & $20(10)$ & $68.9(34.4)$ & $19(3)$ & $86.4(13.6)$ & $190(61)$ & $67.4(21.6)$ \\
\hline North America & 19 & $8 \cdot 2$ & 3 & $10 \cdot 3$ & 3 & $13 \cdot 6$ & 25 & 8.9 \\
\hline South America & 4 & $1 \cdot 7$ & 1 & $3 \cdot 4$ & - & - & 5 & 1.8 \\
\hline Africa & 2 & 0.9 & - & - & - & - & 2 & 0.7 \\
\hline Australasia & 8 & 3.5 & 4 & $13 \cdot 8$ & - & - & 12 & $4 \cdot 3$ \\
\hline
\end{tabular}

*Includes Editorials, Commentaries, Review articles, Horizons in Nutritional Science articles, Letters to the Editor, and Book Reviews.

Table 2. Articles published in British Journal of Nutrition in 2003 and 2004 that were most highly cited in 2005

\begin{tabular}{llcc}
\hline & Type of article & Citations in 2005 & Total citations to date \\
\hline Trayhurn \& Wood (2004) & Horizons & 54 & 79 \\
Zitterman et al. (2003) & Review & 44 & 85 \\
Whanger (2004) & Review & 27 & 42 \\
Wood \& Trayhurn (2003) & Horizons & 23 & 35 \\
Magee \& Rowland (2004) & Review & 20 & 26 \\
Harrold \& Williams (2003) & Horizons & 16 & 23 \\
Kay et al. (2004) & Full paper & 15 & 16 \\
Rayman (2004) & Review & 14 & 16 \\
Tully et al. (2003) & Full paper & 13 & 28 \\
Flint et al. (2004) & Full paper & 13 & 15 \\
Holven et al. (2003) & Full paper & 12 & 22 \\
Burdge et al. (2003) & Full paper & 12 & 21 \\
Trebble et al. (2003) & Full paper & 12 & 20 \\
\hline
\end{tabular}

Data were obtained from ISI Web of Science ${ }^{\circledR}$ on 17 May 2006

\section{Philip C. Calder \\ Editor-in-Chief \\ Institute of Human Nutrition \\ School of Medicine \\ University of Southampton \\ Southampton \\ $U K$ \\ pcc@soton.ac.uk}

\section{References}

Burdge GC, Finnegan YE, Minihane AM, Williams CM \& Wootton SA (2003) Effect of altered dietary $n-3$ fatty acid intake upon plasma lipid fatty acid composition, conversion of $\left[{ }^{13} \mathrm{C}\right]$ alpha-linolenic acid to longer-chain fatty acids and partitioning towards betaoxidation in older men. Br J Nutr 90, 311-321.

Calder PC (2006) Carpe diem. Br J Nutr 95, 1-4.

Flint A, Moller BK, Raben A, Pedersen D, Tetens I, Holst JJ \& Astrup A (2004) The use of glycaemic index tables to predict glycaemic index of composite breakfast meals. Br J Nutr 91, 979-989.

Harrold JA \& Williams G (2003) The cannabinoid system: a role in both the homeostatic and hedonic control of eating? Br J Nutr 90, $729-734$.
Holven KB, Haugstad TS, Holm T, Aukrust P, Ose L \& Nenseter MS (2003) Folic acid treatment reduces elevated plasma levels of asymmetric dimethylarginine in hyperhomocysteinaemic subjects. Br J Nutr 89, 359-363.

Kay CD, Mazza G, Holub BJ \& Wang J (2004) Anthocyanin metabolites in human urine and serum. Br J Nutr 91, 933-942.

Magee PJ \& Rowland IR (2004) Phyto-oestrogens, their mechanism of action: current evidence for a role in breast and prostate cancer. Br J Nutr 91, 513-531.

Rayman MP (2004) The use of high-selenium yeast to raise selenium status: how does it measure up? Br J Nutr 92, 557-573.

Trayhurn P (2002) Citations and 'impact factor' - the Holy Grail. Br J Nutr 88, 1-2.

Trayhurn P (2003) Recently highly cited articles in the British Journal of Nutrition. Br J Nutr 90, 1-2.

Trayhurn P (2004) Recently highly cited articles in the British Journal of Nutrition (including Supplements): an update. $\mathrm{Br} J$ Nutr 92, 1-3.

Trayhurn P (2005) Tempus fugit - evolution and current impact of the British Journal of Nutrition. Br J Nutr 94, 299-301.

Trayhurn P \& Wood IS (2004) Adipokines: inflammation and the pleiotropic role of white adipose tissue. Br J Nutr 92, 347-355.

Trebble T, Arden NK, Stroud MA, Wootton SA, Burdge GC, Miles EA, Ballinger AB, Thompson RL \& Calder PC (2003) Inhibition of tumour necrosis factor-alpha and interleukin 6 production by mononuclear cells following dietary fish-oil supplementation in 
healthy men and response to antioxidant co-supplementation. $\mathrm{Br} J$ Nutr 90, 405-412.

Tully AM, Roche HM, Doyle R, Fallon C, Bruce I, Lawlor B, Coakley D \& Gibney MJ (2003) Low serum cholesteryl ester-docosahexaenoic acid levels in Alzheimer's disease: a case-control study. Br J Nutr 89, 483-489.
Whanger PD (2004) Selenium and its relationship to cancer: an update. Br J Nutr 91, 11-28.

Wood IS \& Trayhurn P (2003) Glucose transporter (GLUT and SGLT): expanded families of sugar transport proteins. Br J Nutr 89, 3-9.

Zitterman A (2003) Vitamin D in preventive medicine: are we ignoring the evidence? Br J Nutr 89, 552-572. 